\title{
Governance during Social Transformations: Challenges for Africa
}

\author{
Mushtaq H. Khan
}

In recent years African countries have faced a barrage of policy advice backed with financial support from development partners urging them to implement 'good governance' reforms. Good governance has come to mean support for improving the enforcement of property rights, the rule of law, fighting corruption and improving accountability. These reforms have enjoyed broad support because many of these goals are desirable in themselves, and in addition, an underlying set of institutional theories suggest that these reforms will make markets more efficient by reducing the transaction costs of enforcing contracts and providing efficient public goods. The reforms have faced two sorts of problems in Africa and elsewhere. First, in conditions of significant underdevelopment, the implementation of these reforms has been rather limited. This is because the enforcement of formal rights and institutions presupposes economic and political conditions that are associated with advanced economies. The economic assumption is that tax revenues are available for the enforcement of a general structure of rights, which is an expensive proposition. An even more important political assumption is that the rights that are to be enforced are sufficiently aligned with the interests of dominant economic and political organizations for their effective enforcement to be feasible. In reality neither of these assumptions holds in the typical developing country and so very limited improvements in governance defined in this have proved feasible. It is therefore not very surprising that good governance reforms have had a very limited effect on growth and development in countries following these policies.

Related to these observations is a more significant criticism: 'good governance' as a policy priority is based on an ahistorical reading of the factors that have driven the transition of largely pre-capitalist economies with low productivity into economies with significant 'modern' sectors with higher levels of productivity. Historically, these transformations have involved a very important role for politics and the state, not in enforcing some pre-existing structure of rights, but rather in changing property rights structures and creating opportunities for the creation of new productive enterprises while managing political stability in contexts where the potential for conflict is very high. Markets, defined as institutions supporting voluntary individual contracting, have always been important for economic activity but have rarely played a dominant role in driving these transformations (Wood 2002; Khan 2004, 2005).

Defining the critical governance capabilities for developing countries in terms of 'good governance' ignores the important transformative governance capabilities that successful developmental states must have. Indeed, the most damaging aspect of the good governance agenda is that it has focused policy attention on a series of reforms that can at best be marginally implemented, and therefore have a marginal effect on the efficiency of markets. The problem is that for developing countries, a small improvement in the efficiency of markets will not address the more fundamental problem that they have very limited productive capabilities to benefit from enhanced market access. What they lack are economic organizations that are productive enough 
to be competitive in a global economy. Growth has recently accelerated in a number of African countries over the last decade, driven by minerals and a few productive sectors, primarily in agro-industries. But for broad-based development to be truly sustainable, social, political and institutional processes have to support the continuous development of new productive capabilities and organizations across the economy. This requires strong governance capabilities but these are not the governance capabilities that the good governance agenda focuses on.

Social transformations that result in the transformation of traditional economies and modes of organization into modern productive ones are clearly likely to be periods of relatively high levels of conflict and vulnerability. These changes inevitably create winners and losers. As a result, they are not only contested, but in many cases the push and pull of politics can hold back the emergence of viable and successful organizations, or create opportunities for unproductive resource grabbing. There are no blueprints that are always successful because initial conditions and inherited property rights structures are different across countries and the political settlements that constrain what can be enforced are also different. Nevertheless, a national policy discourse is vital because rapid transformations do not just happen, they have to be organized and the changes have to have sufficient support for reasonable levels of enforcement. Often what tends to happen is that the reality of the transformation that is actually happening is not understood or analysed even by the elites who are ostensibly leading it. The result is that progress is often unnecessarily slow, the institutional and policy changes are often not the best possible ones, and success is often serendipitous rather than planned. In many cases retrogression can happen with productivity-enhancing transformations being blocked or reversed because opposition was not foreseen and political and institutional responses were not developed. A better understanding of what these transformations involve can help to identify the tasks that have to be accomplished even if the precise institutional and policy solutions will be different across countries because of different initial conditions and political settlements.

\section{The Limits of the Good Governance Agenda}

From the perspective of institutional economics the 'good governance' agenda focuses on strengthening institutional rules that could make markets more efficient by reducing transaction costs. The promotion of good governance can therefore be described as a 'market-enhancing' governance strategy. The specific governance goals in the 'good governance' agenda should not be confused with governance in general, because there are other governance capabilities that are ignored in the good governance approach. We will refer to some of these specific targeted capabilities as developmental, transformational or growth-enhancing governance capabilities. Much confusion has been created by cross-country econometric exercises that have found that richer or better performing countries score higher in terms of their 'good governance' scores. The problem is that the most sophisticated econometric techniques are inadequate for conclusively proving causality: did the prior improvement of good governance scores have an effect on growth and development? The historical evidence suggests that no country achieved significant 'good governance' capabilities before they developed their economy (some of this evidence is reviewed in Khan 2004, 2005; Meisel and Aoudia 2008; Khan 2012a). 
This is not surprising because good governance capabilities are actually capabilities for delivering expensive public goods (like a rule of law) and it is difficult if not impossible to make significant progress in poor economies with limited fiscal resources. Moreover, no amount of enforcement capability is going to result in effective enforcement unless powerful organizations in society find that the enforcement of the rules in question is ultimately in their own interest. This alignment of interests assumes that most organizations in that society are already productive enough to be able to benefit from the enforcement of market rules. The fact that advanced economies appear to approximate 'good governance' is therefore not surprising but this does not necessarily tell us how they got there. The critical policy question is whether significant improvements in good governance are a necessary precondition for development. This is not to deny that small differences in marketenhancing governance are possible and that at the margin these can make some difference, but can these differences possibly explain the huge differences in developmental success across countries?

The problem of looking at cross-country data on governance and economic performance in an ahistorical way is that by looking at the end-state, we can easily miss the processes through which market-enhancing governance developed over time. How did successful countries improve their 'good governance' characteristics? Did they succeed in somehow enforcing market-enhancing property rights and 'good governance' and then develop rapidly as a result? Or did they have other governance capabilities that allowed them to grow, with their 'good governance' capabilities developing as growth generated the productive organizations who would support the enforcement of formal market rules and who had the resources to pay for the delivery and enforcement of these rules? Economic history can interpreted using econometrics to suggest the first possibility (for instance Acemoglu, et al. 2001, 2002) but I believe that a reading of history that focuses on the evidence of processes suggests that the latter is closer to the truth (Khan 2012a).

Successful countries had other 'growth-promoting' governance capabilities that allowed them to sustain growth but these were very different from 'good governance' capabilities. As they grew, good governance capabilities did get stronger and did assist their economic performance. As a result, if we look at the cross-country data we can find evidence that good governance is associated both with higher incomes and to a weaker extent with growth. But these correlations do not tell us how successful countries actually sustained growth for the long periods when good governance was largely missing. Yet for developing economies in Africa and elsewhere, these processes of transformation and the governance capabilities required for sustaining and accelerating the emergence of modern economies and societies are the most important questions for policy.

Rather than having stable property rights, a good rule of law, low corruption and other attributes of good governance from the outset, successful countries typically had a more targeted set capabilities that sustained their transformations. These governance capabilities helped the implementation of strategies to accelerate accumulation and technology acquisition, improve resource allocation and achieve political stabilization in difficult contexts using pragmatic strategies that differed from country to country. Some developers were dramatically successful, others less so. However, for very good reasons, the governance capabilities and political arrangements in successful countries 
display considerable variation across countries, implying that there is no single blueprint for successful transformational governance. To make matters worse, policies and institutional arrangements that worked well in one context can be associated with weaker or negative results in other contexts. For instance, institutions that protected domestic industries and subsidized exports had very positive effects on technology adoption in countries like South Korea where the political settlement allowed firms receiving support in these ways to be effectively disciplined. In Pakistan in the 1960s similar policies for supporting infant industries had less dramatic effects. Here firms could protect themselves from subsidy withdrawal and therefore had much lower compulsions to raise productivity. Indeed in some countries or for some sectors, some strategies of protection and subsidies may actually have had negative effects.

The large variance in the outcomes associated with targeted interventions is of course a major reason why orthodox policy advisors have tried to reduce the policy space for the developing country state and focused on reform on how to make markets more efficient, including good governance reforms. Implicitly, these policies aim to protect developing countries from the possibility of making mistakes by reducing their discretion. The attempt to protect developing countries from the dangers of policy autonomy is not only somewhat patronizing but is actually deeply damaging as well (Fukuyama 2005). Even if some states have made costly mistakes in the past and even if there were 'right policies' known to more intelligent policy-makers from other countries, societies cannot be put on sustainable growth paths by introducing the 'right' policies and limiting the autonomy of their states to make variations thereafter.

Growth requires a continuous adaptation to changing economic and political circumstances and this most vital capability can be destroyed or stunted by strategies that aim to constrain the policy autonomy of policy-makers. Even the most ideological supporters of market economics will concede that within broad limits sustaining growth requires a significant amount of policy autonomy to respond to crisis and challenge in creative ways. Indeed, crisis and challenge can be created by the operation of markets themselves, a fact that we are temporarily reminded of during deep global crises and then tend to forget very rapidly. More seriously, the historical reality is that the ability to act autonomously may be even more important at earlier stages of development because there is actually a much wider range of variation in successful strategies of social transformation than would be conceded by market-fundamentalist economists (Khan 2012a, 2012b).

Growth and development requires nothing less than the transformation of precapitalist, largely agrarian societies into modern productive ones. These processes involve interlinked strategies of accumulation, technology acquisition, and the management of conflicts unleashed by social transformation. As societies have different political, social and economic initial conditions, it is not surprising that they do not follow the same strategies and paths of transformation. Nevertheless, there have been more and less successful policies and strategies, and we can learn from the ways in which countries addressed problems during their transformations even though the precise instruments and methods cannot be copied and replicated (Amsden 2001). The real irony is that by airbrushing out this admittedly messy history, the sequence of reforms identified in the good governance strategy has identified a series of steps that were never actually followed as reform priorities by any successful country making the transition from poverty to development. By setting apparently plausible 
but unachievable good governance capabilities as the policy target, the global policy discourse has set developing countries a goal they cannot possibly achieve and that is unlikely to help them to traverse the developmental transformation any better.

Ultimately, societies have to devise their own political compromises and governance institutions that can pragmatically address their growth challenges as best as possible given their political constraints. However, the diversity of development paths does not of course imply that any strategy is as good as any other. There are many flawed strategies that self-seeking developing country elites have pursued and justified as developmental strategies to the detriment of development. Even if blueprints are not available, the growth-enhancing governance analysis can provide alternative objectives to developing countries against which they can assess the outcomes of their current policies and institutions. The critical observation is only that poor countries should not be attempting to implement a blueprint for any particular type of governance but instead identify areas of governance that are most likely to make a difference given the growth challenges they face. This implies that policy-makers, political leaderships and broader social constituencies should be aware of and engage with their own experiences and those of other countries. What were the critical problems of accumulation, resource allocation and technology adoption faced by rapid developers? How did they address them? Were there differences in their policies and institutions? What would be the best way of addressing these problems in our country? If the instruments and policies followed by another developer are unlikely to be effectively implementable, are there alternative strategies that that could address these problems in our political context?

\section{Transformation Challenges for Governance}

The historical evidence in Asia and elsewhere suggests that developmental transformations have required strong state capabilities for dealing with critical market failures (Amsden 1989; Wade 1990; Khan and Jomo 2000; Lall 2003). However, even when the role of the state in the 'statist' transitions in East Asian countries is widely recognized, liberal economists argue that these experiences cannot be replicated in other countries because their politics and governance capabilities are different. If replication means the reproduction of any particular country's governance strategy in its entirety, we would agree. Instead, the growth-enhancing (or transformational) governance approach identifies structural problems that historical transitions addressed so that contemporary developing societies can address the problems of social transformation with institutions and policies that are likely to at least partially address these problems given their own institutional and political initial conditions, and perhaps with greater social justice and with fewer costly mistakes.

In understanding the challenges facing Africa, we need to keep in mind the structural features of developing countries that require the development of growth-enhancing governance capabilities (Khan 2005). Two areas in particular stand out as requiring attention. First, developing countries require governance capabilities to manage the allocation of rights over valuable resources given that property rights will remain weakly defined during early stages of development. Historical evidence and economic theory both suggest that contrary to good governance theory, the weakness of property rights in developing countries is structural and not entirely due to the greed of political leaderships or their inadequate political will to enforce a rule of law. In 
these contexts, state capabilities for improving resource allocations through nonmarket processes have played a vital role for better or for worse.

An important developmental difference between countries has therefore been the effectiveness of their states in managing non-market institutional solutions to resource allocation problems in contexts of weakly defined rights. The incentives of political elites to pursue strategies that were socially beneficial and not just privately profitable were vitally important. Countries have differed significantly in the degree of injustice and violence during these transitions and in the developmental outcomes they achieved. The challenge is to incrementally improve capabilities for asset and resource allocation using non-market institutional processes. This may also require a restructuring of political organizations to align the incentives of political elites if the political settlement is adverse for development to begin with (Khan 2010). Clearly, this type of 'governance reform' is explicitly political and the experience of other countries can at best serve as a catalyst for political movements within a country to try and restructure domestic politics in more developmental ways. The governance improvements here are bound to be country-specific because what is feasible depends very closely on the initial structure of political organizations in that political settlement and the types of political entrepreneurs and movements that emerge.

Second, development in poor countries is also constrained by a variety of market failures that prevent investment in sectors that require the absorption, adaptation and learning of advanced technologies. Entrepreneurs and their organizations in late developers have to rapidly acquire the tacit knowledge required for using modern technologies at levels of productivity that makes them competitive. The acquisition of these capabilities through investment in learning-by-doing processes faces significant contracting failures that can prevent private investors from organizing the financing for the learning-by-doing. The effectiveness with which technology adoption can be assisted by public policies has therefore been an important dimension of developmental difference across countries. In turn, this has required complementary governance capabilities on the part of the state to provide incentives for learning-bydoing while creating compulsions for entrepreneurs not to waste resources. The experience of East Asia shows that while the institutions and policies for assisting learning differed widely, in the successful cases, policies were compatible with political conditions in ways that allowed the creation of credible incentives and compulsions for learning (Khan 2000; Khan and Blankenburg 2009). The compatibility or otherwise of policies with the political settlement can also help to explain why very similar strategies failed to deliver good results in other countries.

Clearly, compared to the high growth Asian countries, the initial conditions for implementing developmental strategies are relatively adverse in many African countries both in terms of initial entrepreneurial capabilities and the suitability of their political settlements for enforcing developmental policies. Nevertheless, the historical evidence of the types of challenges that need to be addressed during developmental transformations can be useful for identifying feasible incremental strategies of building growth-enhancing governance capabilities in their specific political settlements. A 'good governance' strategy of protecting and enforcing all existing property rights and a rule of law is unlikely to make much progress in the typical developing country. But a strategy to identify the most important property right transformations that are required for the development of the most likely sectors, 
supported by strategies for assisting learning-by-doing and the development of competitiveness in those sectors can pay dividends. The sectors would have to be carefully chosen, and the strategies would have to be compatible with existing technocratic and political enforcement capabilities. In many cases, this would mean that the initial experiments may have to be on a relatively small scale and scaled up when successful. Undoubtedly, any country will make mistakes on the way, as all previous countries have done. Perhaps the most important correction required to our current way of thinking is to understand that the adoption and learning of technological, bureaucratic and governance capabilities is an incremental process that involves making mistakes and learning from them.

\section{References}

Acemoglu, Daron, Simon Johnson and James A. Robinson 2001. The Colonial Origins of Comparative Development: An Empirical Investigation, American Economic Review 91 (5): 1369-401.

Acemoglu, Daron, Simon Johnson and James A. Robinson 2002. Reversal of Fortune: Geography and Institutions in the Making of the Modern World Income Distribution, The Quarterly Journal of Economics 117 (4): 1231-94.

Amsden, Alice 1989. Asia's Next Giant: South Korea and Late Industrialization. Oxford: Oxford University Press.

Amsden, Alice 2001. The Rise of "The Rest": Challenges to the West from LateIndustrializing Economies. Oxford: Oxford University Press.

Fukuyama, Francis 2005. State-Building: Governance and World Order in the Twenty-First Century. London: Profile Books.

Khan, Mushtaq Husain 2000. Rent-seeking as Process, in Khan, Mushtaq H. and K.S. Jomo (eds) Rents, Rent-Seeking and Economic Development: Theory and Evidence in Asia, Cambridge: Cambridge University Press.

Khan, Mushtaq Husain 2004. State Failure in Developing Countries and Strategies of Institutional Reform, in Tungodden, Bertil, Nicholas Stern and Ivar Kolstad (eds) Annual World Bank Conference on Development Economics Europe (2003): Toward Pro-Poor Policies: Aid Institutions and Globalization, Proceedings of Annual World Bank Conference on Development Economics, Oxford: Oxford University Press and World Bank. Available < http://eprints.soas.ac.uk/3683/1/State_Failure.pdf $>$

Khan, Mushtaq Husain 2005. The Capitalist Transformation, in Jomo, K.S. and Erik S. Reinert (eds) Development Economics: How Schools of Economic Thought Have Addressed Development, London and New Delhi: Zed Press and Tulika.

Khan, Mushtaq Husain 2010. Political Settlements and the Governance of GrowthEnhancing Institutions. Research Paper Series on Governance for Growth. School of Oriental and African Studies, University of London: London. Available

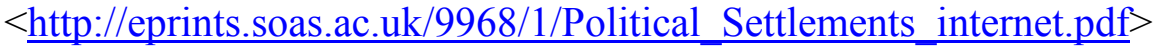


Khan, Mushtaq Husain 2012a. Governance and Growth: History, Ideology and Methods of Proof, in Noman, Akbar, Kwesi Botchwey, Howard Stein and Joseph Stiglitz (eds) Good Growth and Governance for Africa: Rethinking Development Strategies, Oxford: Oxford University Press.

Khan, Mushtaq Husain 2012b. Governance and Growth Challenges for Africa, in Noman, Akbar, Kwesi Botchwey, Howard Stein and Joseph Stiglitz (eds) Good Growth and Governance for Africa: Rethinking Development Strategies, Oxford: Oxford University Press.

Khan, Mushtaq Husain and Stephanie Blankenburg 2009. The Political Economy of Industrial Policy in Asia and Latin America, in Dosi, Giovanni, Mario Cimoli and Joseph E. Stiglitz (eds) Industrial Policy and Development: The Political Economy of Capabilities Accumulation, Oxford: Oxford University Press.

Khan, Mushtaq Husain and K.S. Jomo (eds) 2000. Rents, Rent-Seeking and Economic Development: Theory and Evidence in Asia. Cambridge: Cambridge University Press.

Lall, Sanjaya 2003. Reinventing Industrial Strategy: The Role of Government Policy in Building Industrial Competitiveness. Working Paper Series No. 111. Queen Elizabeth House: Oxford.

Meisel, Nicolas and Jacques Ould Aoudia 2008. Is "Good Governance" a Good Development Strategy? Working Paper No. 58. Agence Française de Développement (AFD): $\quad$ Paris. Available $<$ http://www.afd.fr/webdav/site/afd/shared/PUBLICATIONS/RECHERCHE/Scientifi ques/Documents-de-travail/058-document-travail-VA.pdf $>$

Wade, Robert 1990. Governing the Market: Economic Theory and the Role of Government in East Asian Industrialization. Princeton: Princeton University Press.

Wood, Ellen Meiksins 2002. The Origins of Capitalism: A Longer View. London: Verso. 